JPE (Jurnal Pendidikan Edutama) Vol. 6 No. 1 Januari 2019

P-ISSN : 2339-2258 (Print) E-ISSN: 2548-821X (Online)

http://ejurnal.ikippgribojonegoro.ac.id/index.php/JPE

\title{
ROLE PLAYING ACTIVITY FOR STUDENTS IN NON-ENGLISH STUDY PROGRAM
}

\author{
Irene Brainnita Oktarin \\ Sekolah Tinggi Ilmu Ekonomi Gentiaras \\ email: irenebrainnita@ptsgentiaras.ac.id
}

\begin{abstract}
The researcher conducted research about role playing activity in English for business at Gentiaras College. English for business is a compulsory subject for nonEnglish study program. The purposes of this research were to identify the students' attitude toward role palying activity in the class and the implementation of role play in the class. The participants of this research were 25 students from management study program who took English for business subject. Questionnaire and interview were used for collecting the data. Those data were then analyzed and tabulated. The result of this study is most students have positive attitudes to role playing activity during studying English for business. Given situation based on the topics and playing the role in the class makes the students more motivated to speak English. This activity facilitates them to improve and practice their English speaking ability.
\end{abstract}

Keywords: Role playing, English for business, students' attitude

\begin{abstract}
Abstrak: Peneliti melakukan penelitian tentang aktivitas bermain peran dalam Bahasa Inggris untuk bisnis di STIE Gentiaras. Bahasa Inggris untuk bisnis adalah mata pelajaran wajib untuk program studi non-Bahasa Inggris. Tujuan dari penelitian ini adalah untuk mengidentifikasi sikap mahasiswa terhadap aktivitas bermain peran di kelas dan pelaksanaan bermain peran di kelas. Partisipan dalam penelitian ini adalah 25 mahasiswa dari program studi manajemen yang mengambil mata kuliah Bahasa Inggris untuk bisnis. Kuesioner dan wawancara digunakan untuk mengumpulkan data. Data-data itu kemudian dianalisis dan ditabulasi. Hasil dari penelitian ini adalah sebagian besar mahasiswa memiliki sikap positif terhadap aktivitas bermain peran selama belajar Bahasa Inggris untuk bisnis. Situasi yang diberikan berdasarkan pada topik dan memainkan peran di kelas membuat mahasiswa lebih termotivasi untuk berbicara bahasa Inggris. Kegiatan ini memfasilitasi mereka untuk meningkatkan dan melatih kemampuan berbahasa Inggris mereka.
\end{abstract}

Kata Kunci: Bermain peran, bahasa Inggris untuk bisnis, sikap mahasiswa

\section{INTRODUCTION}

Teaching activity done by teacher will be influenced by teaching method and the perception of that method. There are many methods that can be used to teach English, they are gaming, discussion, role play and presentation. The traditional teaching of ESP has generally focused on the delivery of language information through reading comprehension, writing, vocabulary and grammar exercises neglecting the need to integrate it with skills (Nunan, 2013). However, Johnson,
Keith \& Morrow (1983) believe that interactive teamwork, critical reading and writing, communication skills, negotiation, presentations are some of the vital soft skills for today's academic and future work environment. Foreign languages have been learned not for their own sake but as vehicles for social and economic contacts and for the transportation of ideas. (Kirgloz, 1999)

Students from some study programs will learn English based on their needs. It 
also works at Gentiaras college in which fourth semester students from management are oblidged to take English for business to full fill their English needs. The materials are practical, which mean that the students need to practice speaking English by doing some role. This is the reason in which most lecturers use role play activity as an effective method to teach students. Roleplay is an activity in which the group members are given a situation and vocabularies that are related to the situation. They have to discuss the situation and then role-play the situation in front of the class. This activity is student-centered and the teacher plays the role of a facilitator. A role play is done when students take the part of particular person; a manager, a secretary. They act out the conversation. It means that role play has number of possibilities for communication practice. Role play provides learners to practice speaking English before they do it in real situation. Besides, students also learn in an imaginary situation which is designed as real situation to develop their English ability. This situation will lead students to use English in real life.

It is expected that students can get the basic knowledge of English and help their academic life by implementing role play. However, it is important to know what students' expectation from it? what do they think toward role play in English language learning? Since teaching English is now Student-centered, it is essential to know their perception toward language they have learnt in the class.

\section{RESEARCH DESIGN}

This is a qualitative study; especially case study. This research aims at identifying students' attitude toward role playing activity in the class and how role play technique is implemented. The researcher used questionnaire in the form of likert scale and interview to gain data. The data is then analyzed by using descriptive analysis. There are 25 students as the participants in this research. The questionnaire consists of 15 statements about their attitude toward role playing activity.

\section{RESEARCH FINDINGS}

Students were assigned to do role playing activity as customer service in some public places and telephoning. Besides, they were also assigned to act as the manager of a company that present company profile. These materials are part of English for Business subject that they have to accomplish. From these activity, the researcher tried to identify students' attitude toward activity they have done and the implementation of role play in the class. The finding of research is described in the following paragraph.

\section{Students' Attitude}

The result of questionnaire showed that most students enjoy studying English through role play. The respondent responses (80\%) "strongly agree" and "agree". They agreed that learning English through role play is fun and enjoyable. It also attracts the student's attention in learning English. Since the students have to prepare themselves for their best performance in playing the role, they thought that it is challenging to prepare it. Because it is challenging, the students are motivated to learn English. It can be seen from the result of the questionnaire in which 18 respondents or $75 \%$ of total respondents responses "strongly agree" and "agree". It is also strengthened by the result of questionnaire. Student response whether they are motivated or not when studying English by using role play method. The response is as follow. 
"Sangat termotivasi sekali, saya menjadi sangat bersemangat dalam belajar bahasa inggris"

(I am really motivated and eager to learn English").-student 1-

The other student response:

"Ya, karena setelah saya melakukannya saya merasa senang dan termotivasi untuk menghafal vocab inggris agar saat ada tugas peran saya tidak kesulitan".

(Yes, I am happy and motivated to memorize vocabularies in order that I will not get difficulty during practicing role play).-student 5 -

$15 \%$ respondents response "disagree" toward the statement that role play motivates students. They got difficulty to memorize English vocabulary so that they got difficulty to perform the play. It can be seen from the result of questionnaire below.

"Saya kurang termotivasi karena katakata dalam bahasa Inggris sulit untuk dihafal".

(I am not motivated because English vocabulary is difficult to memorize) student 4-

A role-play uses different communicative techniques and develops fluency in the language, promotes interaction in the classroom and increases motivation (Ladousse, 1995). Role playing can be effectively used in the classroom to motivate and engage students, enhance current teaching strategies, provide real world scenarios to help students learn, learn skills used in real world situations (negotiation, debate, teamwork, cooperation, persuasion), provide opportunities for critical observation of peers (Bonwell \& Eison, 1991). Role-plays are important in the communicative approach because they give learners an opportunity to practice communicating in different social contexts and different social roles (Freeman, 2000). A role-play is a highly flexible learning activity, which has a wide scope for variation and imagination. Moreover, role play can improve learners' speaking skills in any situation and helps learners to interact.

Role play helps students overcome shyness and encourages them to interact with the friends in class. $76 \%$ respondents respond "agree" that they don't feel shy to perform the play. It means that more than a half students feel free and enjoy practicing and performing their role. They are not shy on it. Role play helps the shy learners, where learners with difficulty in conversation are liberated. It is helpful for students to have tried out and experimented with language they will require in the friendly and safe environment of a classroom. Such a technique may help timid students to overcome their shyness of speaking (Ladousse, 1995). The fact that they are someone else makes them feel that their own personality is not implicated. Students can become anyone they like for a short time. Students can also take the opinion of someone else.

Functional language of scenarios can be activated and practiced through role play in imaginary situation. It aims at encouraging students thinking and creativity, letting students develop and practice new language and behavioral skills in a relatively non-threatening setting and can create the motivation and involvement necessary for learning to occur.

Students agree that role playing activity improve their English ability. It can be seen from that data that $88 \%$ of total respondents (22 students) agree on the statement that role play improve their English ability. Through role playing activity, their knowledge is also improved. 
It can also be seen from the result of questionnaire whether there is improvement on their English.

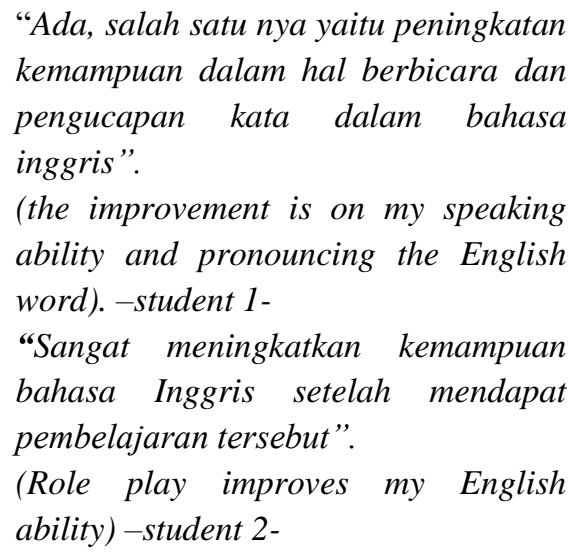

Role play can improve learners' speaking skills in any situation and helps learners to interact. Role play puts students in situation in which they are required touse and develop those phatics forms of language which are so necessary in oiling the works of social relationships. Students need to prepare their role in English (Ladousse, 1995).

Role play provides students with new expressions and vocabulary. The data of questionnaire showed that $60 \%$ respondents (15 students) agree that they get some new vocabulary after doing role playing activity. Since the activity is scripted role play, students need to know the meaning of each expression written. Knowing the meaning of each expression and vocabulary will enable students to play the role and conduct conversation easily. It can be seen from the result of interview whether they learn new vocabulary and expression.

"Iya. Saya mendapatkan banyak kosakata baru yang belum pernah saya dengar sebelumnya. Jadi saya cari artinya dulu sebelum praktek supaya saya mudah mempraktekkan percakapan itu”.
(I get a lot of new vocabulary that I have never known before. I find out the meaning before I practice the play) student 3-

Role-playing develops learners' fluency in speaking (Kowalska, 1991). The wide range of language functions, for example greetings, making arrangements, etc., is exercised more than in any other activities. Learners' focus is put on the communication of meaning rather than on the appropriate use of language. Therefore, through role-playing teachers may train students' speaking skills in any social situations. It means that learners are put in conditions which require speech that is used to communicate socially more than the language necessitated by teaching syllabuses.

\section{Implementation of Role Play}

In the class, performing some role of an employee in certain company that they have prepared before was conducted as a role play. There are three topics in English for Business class that they have to present by using role play. They are practicing making arrangement, telephoning and presenting company profile. In making arrangement topics, students have to pretend themselves as a secretary and a client or a director. They act them out. In presenting company profile, students have to act themselves as the manager of certain company that introduce the company profile. At glance, students performances were good. They can act their role well. However, there are some mistakes that the researcher notice. They commonly did mistakes in grammar and pronunciation. After the students finished performing the play, lecturer gave comment and feedback which is later on beneficial for students to perform the play better. 
Basically, students satisfied with their performance in role play. The data from the questionnaire stated that $80 \%$ respondents satisifed with their performance. They conduct conversations and act as if they were someone they act out. Dialogues, which involve some sort of action or movement, are the ones which work best with the pupils. Intonation is terribly important too, and pupils love to play around with it (Scott and Ytreberg, 2003). In role-play activities, the teacher gives information to the learners such as who they are and what they think or feel. One way of getting student to speak in different social context and to assume varied social roles is to use role-play activities in the classroom. Role plays can be performed from prepared scripts, created from a set of prompt and expression or written using and consolidation knowledge gained from instruction or discussion of the speech act and its variations prior to the role plays themselves.

\section{CONCLUSION}

Role play is an effective method to teach English to non-English study program. This method encourages and motivates students to learn English. Students enjoy the learning process since role play is fun and enjoyable. A great majority students think that role play improve their English speaking ability. Through preparing the script before performing the play, students are automatically learn the vocabulary used for the play. Then they recognize vocabulary that they haven't ever known before. In general, the respondents show positive attitude toward role play method. Only a few students feel shy to perform the play in front of the class. The implementation of role play in the class is done well. However, there were some mistkes in the form of grammar and pronunciation. To make students perform the best, feedback and comments from lecturers must be given.

\section{REFERENCES}

Bonwell, C. C., \& Eison, J. A. (1991). Active learning: Creating excitement in the classroom. Washington, DC: The George Washington University.

Freeman. (2000). Techniques and Principle Teaching. Oxford: Oxford University Press.

Johnson, Keith \& Morrow. (1983). Communication in the Classroom.England: Pearson Education Ltd.

Kirgloz, Y. (1999). Identifying learners' lexical needs through computer analysis of texts language journal Vol.83.

Kowalska, Barbara. (1991). Let them talk in English.

Warszawa:WydawnictwoSzkolne I Pedagogiczne.

Ladousse, G. P. (1995). Role Play: Resources Book for the teacher series. New York: Oxford University Press.

Nunan, D. (2003). Practice English language teaching. New York: McGraw-Hill companies.

Scott E. T., A. W. and Ytreberg, L. H. (2003). Teaching English to Children. Longman Group: UK Limited. 
58 JURNAL PENDIDIKAN EDUTAMA, Vol.6, No.1 Januari 2019 